\title{
Political Connections and Trade Expansion: Evidence from Chinese Private Firms
}

\author{
Yi Lu* \\ National University of Singapore
}

This Version: September 2010

\begin{abstract}
This paper, by using a survey of Chinese private firms in 2004, empirically studies the impacts of political connections (measured as the deputy to the Chinese People's Congress) on trade expansion. It is found that political connections lead to an increase of trade expansion. Meanwhile, the expansion into other administrative areas requires a high hierarchical level of political connections, i.e., at the corresponding administrative level or above. Furthermore, it is found that political connections affect trade expansion by overcoming insecure property rights institutions and inefficient contracting institutions.
\end{abstract}

Keywords: Political Connections, Trade Expansion, Economic Institutions, Chinese People's Congress

JEL Codes: P26, D21, F18

\footnotetext{
${ }^{*}$ Corresponding author: Yi Lu, Department of Economics, National University of Singapore, 1 Arts Link, Singapore, 117570. Tel: 65-6516 6834; Fax: 65-6775 2646; Email: justinly6@gmail.com.
} 


\section{Introduction}

Recently, there is a growing literature investigating the value of political connections. It has been found that political connections improve firm performance (e.g., Johnson and Mitton, 2003; Li et al., 2008) and increase firm value (e.g., Roberts, 1990; Fisman, 2001; Ramalho, 2007; Claessens et al., 2008). It has also been found that political connections help firms gain favors in the market, such as advantageous regulatory conditions (e.g., Agrawal and Knoeber, 2001), access to bank loans (e.g., Bai et al., 2006a; Khwaja and Mian, 2005; Faccio, 2006; Claessens et al., 2008; Li et al., 2008), and secure property rights protection (e.g., Hellman et al., 2003). In this paper, we examine the impacts of political connections on one of the most important firm behaviors, trade expansion ${ }^{1}$, and identify possible mechanisms behind such linkage.

Firms are found to be born largely in the localities where their entrepreneurs reside (Michelacci and Silva, 2007), and later expand to other markets along with their growth. However, trade expansion requires the existence of elaborate economic institutions such as property rights institutions, contracting institutions and financing institutions (Greif, 2006). For example, when the entrepreneur expands his business to distant cities where he is an alien, the concerns are how to protect his properties not being expropriated by local government officials and how to ensure honest compliance to the contract by his distant clients. Poor property rights protection and deficient contract enforcement deter the entrepreneur from carrying out the long distance trade. Meanwhile, the discrimination against firms' access to bank loans binds their capabilities from expansion due to insufficient funds. Under such circumstances, political connections can play a significant role by achieving de facto good property rights protection and contract enforcement, and by obtaining bank loans.

This paper, by using a survey of Chinese private firms in 2004, empirically studies the impacts of the deputy to the Chinese People's Congress (CPC in short henceforth), an important indicator of political connections in China, on trade expansion. The dataset offers us a good setting to investigate the role of political connections. On the one hand, China has maintained its oneparty ruling system and significant government intervention on the economy during the transition from the central planning economy to the market econ-

\footnotetext{
${ }^{1}$ Lopez (1967) argues that long distance trade "became the driving force of economic progress, and in the end affected every aspect of human activity almost as decisively as the Industrial Revolution changed the modern world." Greif (2006) also treats the trade expansion of the late medieval period as a fundamental transformation in the possibilities of the medieval economy.
} 
omy, and there still remains significant discrimination against operations of private firms (Clarke et al., 2008). This provides entrepreneurs with great incentives to enter politics ( $\mathrm{Li}$ et al., 2006). On the other hand, China lacks well-developed economic institutions (Allen et al., 2005) and there are substantial variations in the development of these institutions across various regions (Du et al., 2008). Private firms are thus constrained in their production scales and range of markets. Taken together, this not only allows us to investigate the effect of political connections on trade expansion but also the role of economic institutions underpinning such effect.

Our regression results show that an entrepreneur being a deputy to the CPC sells less in the local county and is more likely to expand his business into other administrative areas. More interestingly, when we decompose the deputy to the CPC into different administrative levels (i.e., town-, county-, prefecture-, and region-level), we find that the expansion into other administrative areas is affected only by the deputy to the CPC at the corresponding administrative level or above. Specifically, the reduction of sales in the local county requires the deputy to the $\mathrm{CPC}$ at the county-level or above, the expansion into other counties in the same region requires the deputy to the $\mathrm{CPC}$ at the prefecture-level or above, and the expansion into other regions requires the deputy to the $\mathrm{CPC}$ at the region-level or above. ${ }^{2}$ Our results remain robust when we use alternative estimation specifications, stepwisely control for entrepreneurial characteristics and firm characteristics along with a set of industrial and regional dummies, and focus on a subsample of firms established mainly by entrepreneurs. Furthermore, we investigate the role of the position in the CPC (i.e., Chairman, Vice-Chairman, or any member in the Standing Committee), and find that it does not have any additional impact on trade expansion.

We next study the role of economic institutions in underpinning the impact of political connections on trade expansion. Three types of economic institutions are identified and investigated: the security of property rights protection, the effectiveness of the contract enforcement, and the development of financial institutions. Specifically, the deputy to the CPC may help the firm in protecting their properties in the regions with less-secure property rights protection, upholding private contracts when the businesses are conducted in the regions with less-efficient contract enforcement, and obtaining bank loans in the less developed financial markets. Our regression results lend support to the argument of property rights protection and contract enforcement but not financial institutions.

\footnotetext{
2 "Region" here refers to 22 provinces, 4 province-level municipalities and 5 minority autonomous regions.
} 
The paper is related to the literature on economic institutions and trade expansion. Dixit (2003) theoretically investigates the relationship between contract enforcement, self-governance, and trade expansion, and argues that self-governance prevails only in a sufficiently small world and costly contract enforcement is useful only in a sufficiently large world. Other contributions on this topic include Ostrom (1990), Ellickson (1991), Kandori (1992), Greif (1993, 1994), Ellison (1994), Li (2003), and Anderson and Young (2006). Meanwhile, our paper is related to the literature on the role of economic institutions on international trade, i.e., Anderson and Marcouiller (2002), Ranjan and Lee (2007), Schuler (2002), Costinot (2004), Méon and Sekkat (2006), and Nunn (2007).

Our study also sheds light on the research about the political economy in China. Contributions include ownership reform (Bai et al., 2000; Li and Xu, 2002; Lin et al., 2005; Lu et al., 2006b), credit allocation (Cull and Xu, 2001, 2003; Gordon and Li, 2003), political personnel control (Li and Zhou, 2005), and local-central fiscal relationships (OKsenberg and Tong, 1991; Bahl and Wallich, 1992; Chung, 1995; Ma, 1995a, 1995b; Qian and Weingast, 1997; Zhang, 1999; Jin et al., 2005).

The paper is organized as follows. Data and variables are discussed in Section 2, and empirical results are presented in Section 3. The paper concludes with Section 4.

\section{Data and Variables}

Our data comes from the Survey of China's Private Enterprises conducted in 2004. The Survey is conducted jointly by the United Front Work Department of the Central Committee of the Communist Party of China, the All China Industry and Commerce Federation, and the China Society of Private Economy at the Chinese Academy of Social Sciences. To achieve a balanced representation across all regions and industries in China, the Survey used multi-stage stratified random sampling method. The total number of private enterprises to be surveyed was first determined. After that, two cities were selected from each of the 31 regions, which included the capital city of the region or one prefecture-level city, and one county-level city. Next, the number of private enterprises to be surveyed in each region was determined by the product of the percentage of the region's share of private enterprises in the national total and the total number of private enterprises in the survey. The same method was used to determine the number of sample firms in every city and industry. Finally, private enterprises were randomly chosen for each sub-sample. The dataset contains 1,613 initial observations, about 0.05 per- 
cent of the total number of private enterprises in China by the end of 2003 . We exclude observations from Tibet as situations in Tibet differ greatly from those in other regions and obtain the final sample with 1,603 observations.

The dependent variable in this paper is the measure of a firm's degree of trade expansion. In the Survey, there is a question asking the entrepreneur about the percentage of sales in the county where he resides, the percentage of sales within the region but outside the county, and the percentage of sales outside the region. Correspondingly, we construct three variables, Percentage of Sales within the County, Percentage of Sales within the Region but outside the County, and Percentage of Sales outside the Region. Summary statistics is reported in Table 1.

The key explanatory variable used here is deputy to the $C P C$, a dummy variable that takes value one if the entrepreneur is a deputy to the CPC and zero otherwise. Despite decades of economic reform in China, private enterprises still face severe political and social discrimination. ${ }^{3}$ For example, there have been several waves of movements cracking down private business in the 1980s ( $\mathrm{Li}$ et al., 2006; Li and Zhou, 2005; Li et al., 2008). Given these adverse political environment, private entrepreneurs have been seeking ways to smooth their operations. One promising way is to actively participate in politics, in particular, becoming deputy to the most influential political body in China, the Chinese People's Congress. There are many advantages with such political connections, for example, access to key resources such as bank loans, land and operation licences, and favorable government polices such as tax benefits and waiver of extralegal payments (Li and Zhou, 2005; Li et al., 2008).

Meanwhile, we decompose the deputy to the CPC into four levels, namely the town-level, the county-level, the prefecture-level, and the region-level or above, and construct four dummy variables correspondingly (i.e., deputy to the CPC at the town-level, deputy to the CPC at the county-level, deputy to the CPC at the prefecture-level, and deputy to the CPC at the region-level or above). Furthermore, we group the deputy to the CPC at all levels into three categories (i.e., the county-level or above, the prefecture-level or above, and the region-level or above), and construct two more dummy variables accordingly (i.e., deputy to the CPC at the county-level or above and deputy to the CPC at the prefecture-level or above). Details about the construction and the data source of variables are discussed in Appendix.

For investigating the role of position in the CPC (i.e., Chairman, ViceChairman, and any member in the Standing Committee) in promoting trade

\footnotetext{
${ }^{3}$ For a comprehensive description of the development of private enterprises in China since 1978, please see Young (1995).
} 
expansion, we construct three dummy variables (i.e., Position in the $C P C$ at the county-level or above, Position in the CPC at the prefecture-level or above, and Position in the CPC at the region-level or above), each taking value one if the entrepreneur has a position in the $\mathrm{CPC}$ at the corresponding administrative level and zero otherwise.

For investigating the mechanisms through which political connections affect trade expansion, we explore the role of economic institutions, i.e., property rights institutions, contracting institutions, and financial institutions (details will be provided below in Section 3.2).

In the empirical analysis, we also control for other factors that might affect a firm's trade expansion. Variable related to entrepreneurial characteristics include: Age (measured by the age of an entrepreneur by the end of 2003), Education (measured by years of formal education), Managerial Experience (a dummy variable that takes value one if the entrepreneur had a managerial position before he or she started his or her own business and zero otherwise), and Party Member (a dummy variable that takes value one if the entrepreneur is a member of the Chinese Communist Party and zero otherwise). Variables related to firm characteristics include: Firm Age (measured by the logarithm of years of establishment), and Firm Size (measured by the logarithm of total assets).

\section{$3 \quad$ Empirical Results}

\subsection{Political Connections and Trade Expansion}

To investigate the impacts of political connections on trade expansion, we estimate the following equation:

$$
y_{e i r}=\alpha_{i}+\beta \cdot P_{e i r}+\delta_{r}+X_{e i r}^{\prime} \gamma+\varepsilon_{e i r}
$$

where $y_{e}$ is the measure of firm $e$ 's degree of trade expansion (i.e., Percentage of Sales within the County, Percentage of Sales within the Region but outside the County, and Percentage of Sales outside the Region) in industry $i$ and region $r ; P_{e i r}$ is the measure of firm $e$ 's political connections (i.e., deputy to the $C P C) ; \alpha_{i}$ is the industrial dummy; $\delta_{r}$ is the regional dummy; $X_{\text {eir }}$ is a set of controls (i.e., firm and entrepreneurial characteristics); and $\varepsilon_{\text {eir }}$ is the error term. Standard errors are clustered at the region to deal with the possible heteroskadesticity problem.

Equation (1) is estimated by the Tobit regression and the results are reported in Table 2. Each cell in the table represents a separate regression and all regressions include a set of industrial and regional dummies but not 
reported to save space. In Column 1, deputy to the $C P C$ is used as the explanatory variable. It is found that deputy to the $C P C$ has a statistically significant and negative impact on the percentage of sales within the county, and a positive effect on the expansion into other areas in the same region and into other regions though not statistically significant. Specifically, the change from a non-deputy to a deputy to the CPC is associated with a 0.37-standarddeviation reduction of the percentage of sales within the county, a 0.09standard-deviation increase of the percentage of sales within the region but outside the county, and a 0.05-standard-deviation increase of the percentage of sales outside the region.

Columns 2-5 of Table 2 use the deputy to the CPC decomposed at four levels (i.e., the town-level, the county-level, the prefecture-level, and the region-level or above) as the explanatory variable. Interestingly, it is found that the expansion into other administrative areas is affected only by the deputy to the CPC at the corresponding administrative level or above. In particular, the reduction of sales within the county is just negatively and statistically significantly affected by the deputy to the CPC at the countylevel or above (see Columns 2-5 of Panel A of Table 2). And the expansion of trade into other areas in the region is positively and statistically significantly affected by the deputy to the CPC at the prefecture-level (see Columns 2-5 of Panel B of Table 2). Meanwhile, the expansion of trade into other regions is positively and statistically significantly affected by the deputy to the CPC at the region-level or above (see Columns 2-5 of Panel $\mathrm{C}$ of Table 2).

Overall, our results from Table 2 confirm the positive effect of political connections on trade expansion and suggest that the effect requires a high hierarchical level of political connections. To further investigate the role of political connections, we group the deputy to the $\mathrm{CPC}$ at four levels into three categories, the deputy to the CPC at the county-level or above, the deputy to the CPC at the prefecture-level or above, and the deputy to the $\mathrm{CPC}$ at the region-level or above, and repeat the analysis. Regression results are reported in Table 3 . Column 1 shows that the deputy to the CPC at the county-level or above has a statistically significant and negative impact on the firm's sale in the local county. Specifically, being a deputy to the CPC at the county-level or above is associated with a 0.40 -standard-deviation decrease of the percentage of sales within the county. Column 2 shows that the deputy to the CPC at the prefecture-level or above has a statistically significant and positive impact on the firm's expansion into other areas in the region. Specifically, being a deputy to the CPC at the prefecture-level or above is associated with a 0.25 -standard-deviation increase of the percentage of sales within the region but outside the county. Column 3 shows that the deputy to the CPC at the region-level or above has a statistically significant 
and positive impact on the firm's expansion into other regions. Specifically, being a deputy to the CPC at the region-level or above is associated with a 0.60-standard-deviation increase of the percentage of sales outside the region.

As the location of sales (for example, how much to sell within the county or beyond the county) is jointly determined by the entrepreneur, one may be concerned that this simultaneity in decisions may bring the correlation in error terms in the three separate regressions reported in Table 3. To address this concern, we repeat the analysis by using the seemingly unrelated regression estimation. As shown in Table 4, our results regarding political connections and trade expansion is robust to this estimation specification.

One may argue that our main results in Tables 2-4 could be biased due to omitted variables although industrial and regional dummies have already been included. To alleviate such concern, we stepwisely include the entrepreneurial characteristics, firm characteristics and the location of headquarters, and regression results are reported in Table 5. It is clear that our results remain robust to these controls except that the impact of the deputy to the $\mathrm{CPC}$ at the prefecture-level or above is not statistically significant.

Another concern for our results is the reverse causality, namely, it is trade expansion affecting the level of political connections while not the opposite. The concern may not be relevant in our case as deputies to the CPC in our analysis were elected in 2001 while sales figures were 2003 values. ${ }^{4}$ However, it is still arguable that the pattern of trade may persist over time and the reverse causality remains possible. As a further robustness check, we use the instrumental variable estimation. Specifically, the instrument is an indicator of whether the entrepreneur's first job is government official or soldier. According to the Election Law of People's Republic of China, deputies to the CPC at the county are elected directly by their constituencies, while deputies to the CPC above the county-level are elected by the people's congresses at the next lower level. However, in reality, deputies to the CPC at every level are largely appointed by local government and party leaders. Thus, it is expected that entrepreneurs with government and army background are more likely to become deputies to the CPC. And to alleviate the concern that the affiliation with government and army is endogenous, we use the information about the entrepreneur's first job to construct the instrumental variable. The instrumental variable estimation results are reported in Table 6. As shown in Column 2, the instrumental variable is positively and statistically significantly correlated with the endogenous variable, consistent with the above

\footnotetext{
${ }^{4}$ The term of office for the deputy to CPC is five years. Every five years there are elections at expiration of office terms, and newly elected deputies constitute the new session of people's congresses and fulfill their responsibilities.
} 
argument. With respect to the central issue, the deputy to the CPC at the county-level or above, after instrumented, still has a statistically significant and negative impact on the firm's sale in the local county. ${ }^{5}$

Moreover, some of China's private enterprises were transformed from state-owned enterprises as a result of privatization, and state-owned enterprises have been known for their connections with the governments. Thus, a potential concern is that the degree of trade expansion could be due to the legacies of pre-privatization connections. To alleviate this concern, we restrict our sample to those firms that were established mainly by entrepreneurs, ${ }^{6}$ and repeat the analysis. As summarized in Table 7, our main results are robust to this subsample.

Finally, we investigate the role of the position in the $\mathrm{CPC}$ on trade expansion. We include a dummy variable indicating whether the entrepreneur has a position in the CPC, and repeat the analysis. Results are reported in Table 8. It is clear that the position in the CPC does not have any additional impact on trade expansion, and our main results remain robust to this practice.

\subsection{Political Connections, Economic Institutions, and Trade Expansion}

The role of economic institutions on the pattern of trade has recently been recognized by economists. In comparing the practices between Maghribi traders and Genoese traders in medieval Europe, Grief (1993, 1994, 2006) argues that Genoese are able to expand the range of their markets through reliance on formal economic institutions while Maghribi traders fail in long distance trade because they rely on the informal self-governance (i.e., reputation) system. In studying entrepreneurs in emerging markets, McMillan and Woodruff (2002) contend that the lack of efficient economic institutions make entrepreneurs to conduct businesses with their acquaintances who are often located in the same neighborhood.

To investigate the role of economic institutions behind the impact of

\footnotetext{
${ }^{5}$ Note that even though we use the entrepreneur's first job to construct the instrumental variable, it is possible that entrepreneurs whose first job are government officials or soldiers have different features from those whose first job are not government officials or soldiers, implying the bias with the instrumental variable estimation. In general, it is hard to tackle the issues of omitted variables and reverse causality (see Li et al., 2007). As a result, our findings are subject to alternative interpretations.

${ }^{6}$ We use $50 \%$ of total investment capitals invested by the entrepreneur at the time of firm establishment as the criterion to judge whether the firm was established mainly by the entrepreneur.
} 
political connections on trade expansion, we estimate the following equation

$$
y_{\text {eir }}=\alpha_{i}+\beta \cdot P_{\text {eir }}+\eta \cdot P_{\text {eir }} \cdot R_{r}+\delta_{r}+X_{\text {eir }}^{\prime} \gamma+\varepsilon_{\text {eir }}
$$

where $R_{r}$ is the regional measure of economic institutions. Standard errors are clustered at the region, allowing for arbitrary correlation within the region. Since the measure of economic institutions is only available at the region-level, we have to focus on the regression of the expansion into other regions on the deputy to the $\mathrm{CPC}$ at the region-level or above.

In recognition of the literature of the economic institutions on trade expansion, we measure economic institutions by three ways, i.e., property rights institutions, contracting institutions, and financial institutions. Until recently, China provided little formal protection of private property, and its legal system was far from independent (Blanchard and Kremer 1997; Rodrik 2004a and 2004b; Allen, Qian, and Qian 2005; Economist, March 15, 2008). It is expected that other things being equal, the entrepreneur is less likely to expand his businesses into regions with less-secure property rights protection and less-efficient contract enforcement, and the deputy to the CPC entitled with significant state power enhances the likelihood of expansion into those regions. We define property rights institutions as the severity of extralegal payments to the government and informal levies (see also North 1991; Johnson, McMillan, and Woodruff, 2002; Acemoglu and Johnson, 2005). Specifically, the measure is from the Survey of China's Private Enterprises in 2000, in which there are two questions asking the entrepreneur whether the problem of extralegal payments to the government ( Tan Pai in Chinese) and whether the problem of informal levies ( $Z a F e i$ in Chinese) in the entrepreneur's region is severe according to his or her knowledge. The answer is a number that ranges from 1 to 3 with a higher value indicating a less severe problem. Since the correlation of these two answers for any given firm is very high, we use the principal component method to combine them and generate a single index, and then aggregate the index at the firm-level to the region-level. The index of Property Rights Institutions used in this analysis is the average of values in regions other than the region where the firm is located, and a higher value indicates better property rights protection outside the region. The measure of contracting institutions is constructed in a similar manner. In Fan et al. (2003)'s China Regional Marketization Indices, there is a sub-index on legal institutions and contract enforcement. It is the proportion of lawyers in a region's total population. We use it as the measure of contracting institutions in our analysis (see also Du et al., 2008), and compute the average of values in regions other than the region where the firm is located, with a higher value indicating better contract enforcement outside the region. 
Meanwhile, China has long maintained a financial repression regime and private firms are typically denied access to bank loans (Li, 2001; Lal, 2006). Financial institutions may affect a firm's capability to expand because private firms in China are often short of capital (Huang, 2003), and political connections is found to enhance private firms' access to bank loans (Bai et al., 2006a; Li et al., 2008). It is thus expected that the deputy to the CPC may grant the entrepreneur favors in accessing bank loans in less-developed financial markets and thus enhance his capability to expand the business. The measure of regional financial development comes from the National Bureau of Statistics (2004). It is the ratio of state-owned banks credit to GDP and the higher value indicates worse development of financial markets (see Boyreau-Debray, 2004 for the discussion about indicators of financial institutions in China).

Regression results are reported in Table 9 . Column 1 shows that the interaction term between the deputy to the $\mathrm{CPC}$ at the region-level or above and property rights institutions has a negative and statistically significant coefficient, suggesting that political connections help a firm in expanding its trade in the absence of secure property rights protection. Column 2 shows that the interaction term between the deputy to the CPC at the region-level or above and contracting institutions has a negative and statistically significant coefficient, suggesting that political connections help a firm in expanding its trade in the absence of efficient contract enforcement. Column 3 shows that the interaction term between the deputy to the CPC at the region-level or above and financial institutions has a positive but not statistically significant coefficient, suggesting that political connections do not help a firm in expanding its trade in the absence of developed financial institutions. Overall, these results lend support to the argument of property rights institutions and contracting institutions but not financial institutions.

\section{Conclusion}

The research on the value of political connections has attracted economists' interests in the recent years. Various studies have shown that political connections give firms many kinds of advantages in the market, and ultimately increase firm value and firm performance. In this paper, we investigate the impact of political connections on trade expansion, and explore the role of economic institutions behind such linkage.

Our regression results show that political connections, measured as the deputy to the CPC, has a positive impact on the firm's degree of trade expansion. Specifically, being a deputy to the CPC reduces the percentage 
of sales in the local county, and increases the trade into other counties in the same region and into other regions. We then decompose the deputy of CPC into four administrative levels, and find that the expansion into other administrative areas requires the deputy of $\mathrm{CPC}$ at the corresponding administrative level or above. The results are robust to different estimation specifications, a host of controls, and a subsample. Meanwhile, the role of the position in the $\mathrm{CPC}$ is found to have no additional impact on trade expansion. Furthermore, our results find the support to the argument that political connections affect trade expansion by overcoming insecure property rights institutions and inefficient contracting institutions in other regions.

\section{References}

Acemoglu, Daron and Simon Johnson, 2005. "Unbundling Institutions", Journal of Political Economy 113, 949-995.

Agrawal, Anup, and Charles R. Knoeber, 2001. "Do Some Outside Directors Play a Political Role?", Journal of Law and Economics 44, 179-198.

Anderson, James E. and Douglas Marcouiller, 2002. "Insecurity and the Pattern of Trade: an Empirical Investigation", Review of Economics and Statistics 94, 342-352.

Anderson, James E. and Leslie Young, 2006. "Trade and Contract Enforcement", Contributions to Economic Analysis and Policy 5, 1-33.

Allen, Franklin, Jun Qian, and Meijun Qian, 2005. "Law, Finance, and Economic Growth in China", Journal of Financial Economics 77, 57-116.

Bahl, Roy W. and Christine Wallich, 1992. "Intergovernmental fiscal relations in China", Policy Research Working Paper Series 863, The World Bank.

Bai, Chong-en, David D. Li, Zhigang Tao, and Yijiang Wang, 2000. "A Multitask Theory of State Enterprise Reform", Journal of Comparative Economics 28, 716-738.

Bai, Chong-en, Jiangyong Lu, and Zhigang Tao, 2006a. "Property Rights Protection and Access to Bank Loans: Evidence from Private Enterprises in China", Economics of Transition 14, 611-628.

Bai, Chong-en, Jiangyong Lu, and Zhigang Tao, 2006b. "The Multitask Theory of State Enterprise Reform: Empirical Evidence from China", American Economic Review Papers and Proceedings 96, 353-357.

Blanchard, Olivier and Michael Kremer, 1997. "Disorganization", Quarterly Journal of Economics 112, 1091-1126.

Boyreau-Debray, Genevieve, 2004. "Financial Intermediation and Growth: Chinese Style", Policy Research Working Paper No. 3027, The World Bank. 
Chung, Jae Ho, 1995. "Studies of Central-Provincial Relations in the People's Republic of China: A Mid-Term Appraisal", China Quarterly 142, 487-508.

Clarke Donald, Peter Murrell, and Susan Whiting, 2008. "The Role of Law in China's Economic Development", in Thomas Rawski and Loren Brandt (ed.), China's Great Economic Transformation (Cambridge University Press, 2008), 375-428.

Claessens, Stijn, Erik Feijen, and Luc Laeven, 2008. "Political Connections and Preferential Access to Finance: The Role of Campaign Contributions", Journal of Financial Economics 88, 554-580.

Costinot, Arnaud, 2004. "Imperfect Contract Enforcement, Firm Size, and the Pattern of Trade", working paper, Princeton University.

Cull, Robert and Lixin Colin Xu, 2001. "Bureaucrats, State Banks, and the Efficiency of Credit Allocation: The Experience of Chinese State-Owned Enterprises", Journal of Comparative Economics 28, 1-31.

Cull, Robert and Lixin Colin Xu, 2003. "Who Gets Credit? The Behavior of Bureaucrats and State Banks in Allocating Credit to Chinese SOEs", Journal of Development Economics 71, 533-539.

Du, Julan, Yi Lu, and Zhigang Tao, 2008. "Economic Institutions and FDI Location Choice: Evidence from US Manufacturing Firms in China", Journal of Comparative Economics, forthcoming.

Djankov, Simeon, Rafael La Porta, Florencio Lopez-de-Silanes, and Andrei Shleifer, 2002. "The Regulation of Entry", Quarterly Journal of Economics 117, 1-37.

Economist, 2008. "Economics and the Rule of Law", March 15, 2008, 83-85.

Ellickson, Robert G., 1991. Order without Law: How Neighbors Settle Disputes, Cambridge, Mass.: Harvard University Press.

Ellison, Glenn, 1994. "Cooperation in the Prisoner's Dilemma with Anonymous Random Matching", Review of Economic Studies 61, 567-588.

Faccio, Mara, 2006. "Politically Connected Firms", American Economic Review 96, 369-386.

Fan, Gang, Xiaolu Wang, and Henpeng Zhu, 2003. Reports on the Relative Progress of Marketization in Different Regions in China, Economic Science Publishing House, China.

Fisman, Raymond, 2001. "Estimating the Value of Political Connections", American Economic Review 91, 1095-1102.

Gordon, Roger H. and Wei Li, 2003. "Government as a Discriminating Monopolist in the Financial Market: The Case of China", Journal of Public Economics 87, 283-312. 
Greif, Avner, 1993. "Contract Enforceability and Economic Institutions in Early Trade: The Maghribi Traders' Coalition", American Economic Review 83, 525-548.

Greif, Avner, 1994. "Cultural Beliefs and the Organization of Society: A Historical and Theoretical Reflection on Collectivist and Individualist Societies", Journal of Political Economy 102, 912-950.

Greif, Avner, 2006. Institutions and the Path to the Modern Economy: Lessons from Medieval Trade, Cambridge University Press.

Hellman, Joel S., Geraint Jones, and Daniel Kaufmann, 2003. "Seize the State, Seize the Day: State Capture, Corruption and Influence in Transition", Journal of Comparative Economics 31, 751-773.

Huang, Yasheng, 2003. Selling China: Foreign Direct Investment During the Reform Era, New York, NY: Cambridge University Press.

Jin, Hehui, YIngyi Qian, and Barry Weingast, 2005. "Regional Decenralization and Fiscal Incentives: Federalism, Chinese Style", Journal of Public Economics 89, 1719-1742.

Johnson, Simon and Todd Mitton, 2003. "Cronyism and Capital Controls: Evidence From Malaysia", Journal of Financial Economics 67, 351382 .

Johnson, Simon, John McMillan, and Christopher Woodruff, 2002. "Property Rights and Finance", American Economic Review 22, 1335-1356.

Kandori, Michihiro, 1992. "Social Norms and Community Enforcement", Review of Economic Studies 59, 63-80.

Khwaja, Asim Ijaz and Atif Mian, 2005. "Do Lenders Favor Politically Connected Firms? Rent Provision in an Emerging Financial Market", Quarterly Journal of Economics 120, 1371-1411.

Lal, Deepak, 2006. "A Proposal to Privatize Chinese Firms and End Financial Repression", Cato Journal, Vol. 26, No. 2: 275-286.

Levchenko, Andrei, 2007. "Institutional Quality and International Trade", Review of Economic Studies 74, 791-819.

Li, David D., 2001. "Beating the Trap of Financial Repression in China", Cato Journal, Vol. 21, No. 1, 77-90.

Li, Hongbin, Pak Wai Liu, Ming Ma, and Junsen Zhang, 2007. "Economic Returns to the Communist Party Membership: Evidence from Chinese Twins", Economic Journal 117, 1504-1520.

Li, Hongbin, Lingsheng Meng, Qian Wang, and Li-An Zhou, 2008. "Political Connections, Financing and Firm Performance: Evidence from Chinese Private Firms", Journal of Development Economics 87, 283-299.

Li, Hongbin, Lingsheng Meng, and Junsen Zhang, 2006. "Why Do Entrepreneurs Enter Politics?", Economic Inquiry 44, 559-578. 
Li, Hongbin and Li-an Zhou, 2005. "Political Turnover and Economic Performance: The Disciplinary Role of Personnel Control in China", Journal of Public Economics 89, 1743-1762.

Li, Shuhe, 2003. "Relation-based versus Rule-based Governance: an Explanation of the East Asian Miracle and Asian Crisis", Review of International Economics 11, 651-673.

Li, Wei and Lixin Colin Xu, 2002. "The Political Economy of Telecom Privatization and Competition", Journal of Comparative Economics 30, 439462.

Lin, Yimin, Lixin Colin Xu, and Tian Zhu, 2005. "Politician Control, Agency Problems, and Ownership Reform: Evidence from China", Economics of Transition 13, 1-24.

Lopez, Robert S., 1967. The Birth of Europe, London: M. Evans.

Ma, Jun, 1995a. "The Reform of Intergovernmental Fiscal Relations in China", Asian Economic Journal 9, 205-232.

Ma, Jun, 1995b. "Modelling Central-Local Fiscal Relations in China", China Economic Review 6, 105-136.

McMillan, John and Christopher Woodruff, 2002. "The Central Role of Entrepreneurs in Transition Economies", Journal of Economic Perspectives 16, 153-170.

Méon, Pierre-Guillaume, and Khalid Sekkat, 2006. "Institutional Quality and Trade: Which Institutions? Which Trade?", working paper, DULBEA.

Michelacci, Claudio and Olmo Silva, 2007. "Why so Many Local Entrepreneurs?", Review of Economics and Statistics 89, 615-633.

National Bureau of Statistics, 2004. China Statistical Yearbook for Regional Economy, China Financial and Economic Publishing House.

North, Douglass C., 1991. "Institutions", Journal of Economic Perspectives 5, 97-112.

Nunn, Nathan, 2007. "Relationship-Specificity, Incomplete Contracts and the Pattern of Trade", Quarterly Journal of Economics 122, pp. 569-600.

Oksenberg, Michel and James Tong, 1991. "The Evolution of CentralProvincial Fiscal Relations in China, 1971-1984: The Formal System", China Quarterly 125, 1-32.

Ostrom, Elinor, 1990. Governing the Commons: The Evolution of Institutions for Collective Action, Cambridge: Cambridge University Press.

Qian, Yingyi and Barry Weingast, 1997. "Federalism as a Commitment to Preserving Market Incentives", Journal of Economic Perspectives 11, 8392.

Ranjan, Priya, and Jae Young Lee, 2007. "Contract Enforcement and International Trade", Economics and Politics 19, 191-218. 
Ramalho, Rita, 2007. "The Persistence of Corruption: Evidence from the 1992 Presidential Impeachment in Brazil", Working paper, World Bank.

Roberts, Brian E., 1990. "A Dead Senator Tells No Lies: Seniority and the Distribution of Federal Benefits", American Journal of Political Science 34, 31-58.

Rodrik, Dani, 2004a. "Rethinking Economic Growth in Developing Countries", The Luca d'Agliano Lecture.

Rodrik, Dani, 2004b. "Getting Institutions Right", DICE Report 2/2004, CESifo, 10-15.

Schuler, Philip, 2002. "Institutions and the Changing Composition of International Trade in the Post-Socialist Transition", Ph.D. Dissertation, University of Maryland.

Young, Alwyn, 2000. "The Razor's Edge: Distortions and Incremental Reform in the People's Republic of China", Quarterly Journal of Economics 115, 1091-1135.

Young, Susan, 1995. Private Business and Economic Reform in China, New York: M.E. Sharpe.

Zhang, Le-Yin, 1999. "Chinese Central-Provincial Fiscal Relationships, Budgetary Decline and the Impact of the 1994 Fiscal Reform: An Evaluation", China Quarterly 157, 115-141. 
Appendix: Measurement and Source for Key Variables

Variable
Deputy to the CPC
Deputy to the CPC at the town-level
Deputy to the CPC at the county-level
Deputy to the CPC at the prefecture-level
Deputy to the CPC at the region-level or above

Deputy to the CPC at the county-level or above

Deputy to the CPC at the prefecture-level or above

Age

\section{Education}

\section{Managerial Experience}

\section{Party Member}

Firm Age

Firm Size

First Job as Government Cadre or Soldier

Position in the CPC at the county-level or above

a dummy variable that takes value one if the entrepreneur is the
deputy to the CPC and zero otherwise

a dummy variable that takes value one if the entrepreneur is the deputy to the CPC at the town-level and zero otherwise

a dummy variable that takes value one if the entrepreneur is the deputy to the CPC at the county-level and zero otherwise

a dummy variable that takes value one if the entrepreneur is the deputy to the CPC at the prefecture-level and zero otherwise a dummy variable that takes value one if the entrepreneur is the deputy to the CPC at the region-level or above and zero otherwise a dummy variable that takes value one if the entrepreneur is the deputy to the CPC at the county-level or above and zero otherwise a dummy variable that takes value one if the entrepreneur is the deputy to the CPC at the prefecture-level or above and zero otherwise

the age of an entrepreneur by the end of 2003

the number of years entrepreneurs had in formal education a dummy variable that takes value one if the entrepreneur had held a managerial position before he or she started his or her own business and zero otherwise

a dummy variable that takes value one if the entrepreneur is a member of Chinese Communist Party and zero otherwise

the logarithm of years of establishment

the logarithm of total assets

a dummy variable that takes value one if the entrepreneur's first job is either government official or soldier and zero otherwise a dummy variable that takes value one if the entrepreneur has a position in the CPC at the county-level or above and zero

otherwise
Survey of China's Private

Enterprises in 2004

Survey of China's Private

Enterprises in 2004

Survey of China's Private

Enterprises in 2004

Survey of China's Private

Enterprises in 2004

Survey of China's Private

Enterprises in 2004

Survey of China's Private

Enterprises in 2004

Survey of China's Private Enterprises in 2004

Survey of China's Private

Enterprises in 2004

Survey of China's Private

Enterprises in 2004

Survey of China's Private Enterprises in 2004

Survey of China's Private

Enterprises in 2004

Survey of China's Private

Enterprises in 2004

Survey of China's Private

Enterprises in 2004

Survey of China's Private

Enterprises in 2004

Survey of China's Private

Enterprises in 2004 
Position in the CPC at the prefecture-level or above

Position in the CPC at the region-level or above

Property Rights Institutions

Contracting Institutions

Financial Institutions a dummy variable that takes value one if the entrepreneur has a position in the CPC at the prefecture-level or above and zero

otherwise

a dummy variable that takes value one if the entrepreneur has a position in the CPC at the region-level or above and zero

otherwise

the average of the severity of extralegal payments to the

government and informal levies in regions other than the region where the entrepreneur residents

the average of the ratio of lawyers to population in regions other

than the region where the entrepreneur residents

the ratio of state-owned banks credit to GDP in the region where

the entrepreneur residents
Survey of China's Private Enterprises in 2004

Survey of China's Private Enterprises in 2004

Survey of China's Private Enterprises in 2000

Fan, Wang, and Zhu, 2003 China Statistical Yearbook for Regional Economy 2004 
Table 1: Summary Statistics

\begin{tabular}{|c|c|c|c|c|c|}
\hline Variable & Obs & Mean & Std. Dev. & Min & Max \\
\hline Percentage of Sales within the County & 1,603 & 0.535 & 0.430 & 0 & 1 \\
\hline $\begin{array}{l}\text { Percentage of Sales within the Region but outside } \\
\text { the County }\end{array}$ & 1,603 & 0.445 & 0.397 & 0 & 1 \\
\hline Percentage of Sales outside the Region & 1,603 & 0.406 & 0.417 & 0 & 1 \\
\hline Deputy to the CPC & 1,603 & 0.216 & 0.412 & 0 & 1 \\
\hline Deputy to the CPC at the town-level & 1,603 & 0.037 & 0.190 & 0 & 1 \\
\hline Deputy to the CPC at the county-level & 1,603 & 0.094 & 0.291 & 0 & 1 \\
\hline Deputy to the CPC at the prefecture-level & 1,603 & 0.064 & 0.244 & 0 & 1 \\
\hline Deputy to the CPC at the region-level or above & 1,603 & 0.022 & 0.146 & 0 & 1 \\
\hline $\begin{array}{l}\text { Deputy to the CPC at the county-level or above } \\
\text { Deputy to the CPC at the prefecture-level or }\end{array}$ & 1,603 & 0.179 & 0.384 & 0 & 1 \\
\hline above & 1,603 & 0.085 & 0.280 & 0 & 1 \\
\hline Age & 1,592 & 44.068 & 7.797 & 23 & 83 \\
\hline Education & 1,598 & 13.746 & 2.790 & 6 & 19 \\
\hline Managerial Experience & 1,603 & 0.405 & 0.491 & 0 & 1 \\
\hline Party Member & 1,603 & 0.336 & 0.473 & 0 & 1 \\
\hline Firm Age & 1,523 & 1.939 & 0.578 & 0 & 2.996 \\
\hline Firm Size & 1,603 & 5.326 & 1.621 & 0 & 12.478 \\
\hline First Job as Government Cadre or Soldier & 1,419 & 0.109 & 0.312 & 0 & 1 \\
\hline $\begin{array}{l}\text { Position in the CPC at the county-level or above } \\
\text { Position in the CPC at the prefecture-level or }\end{array}$ & 1,603 & 0.050 & 0.218 & 0 & 1 \\
\hline above & 1,603 & 0.018 & 0.133 & 0 & 1 \\
\hline Position in the CPC at the region-level or above & 1,603 & 0.001 & 0.035 & 0 & 1 \\
\hline Property Rights Institutions & 30 & 0.004 & 0.010 & -0.036 & 0.019 \\
\hline Contracting Institutions & 30 & 4.227 & 0.179 & 3.421 & 4.373 \\
\hline Financial Institutions & 30 & 0.154 & 0.183 & 0.073 & 0.310 \\
\hline
\end{tabular}


Table 2: Political Connections and Trade Expansion

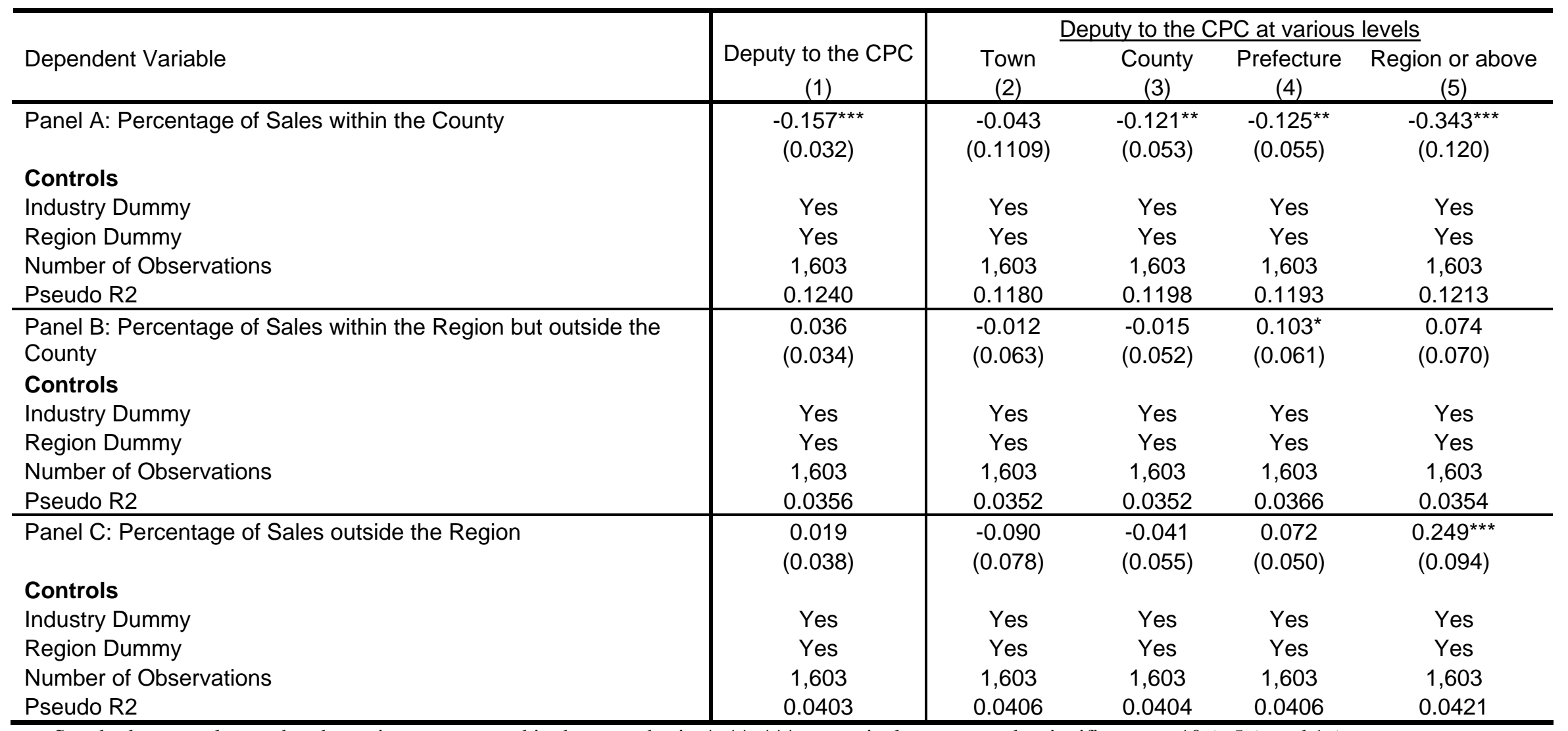

Standard errors, clustered at the region, are reported in the parenthesis. *, **, *** respectively represent the significance at $10 \%$, 5\%, and $1 \%$. 
Table 3: Political Connections and Trade Expansion, further investigation

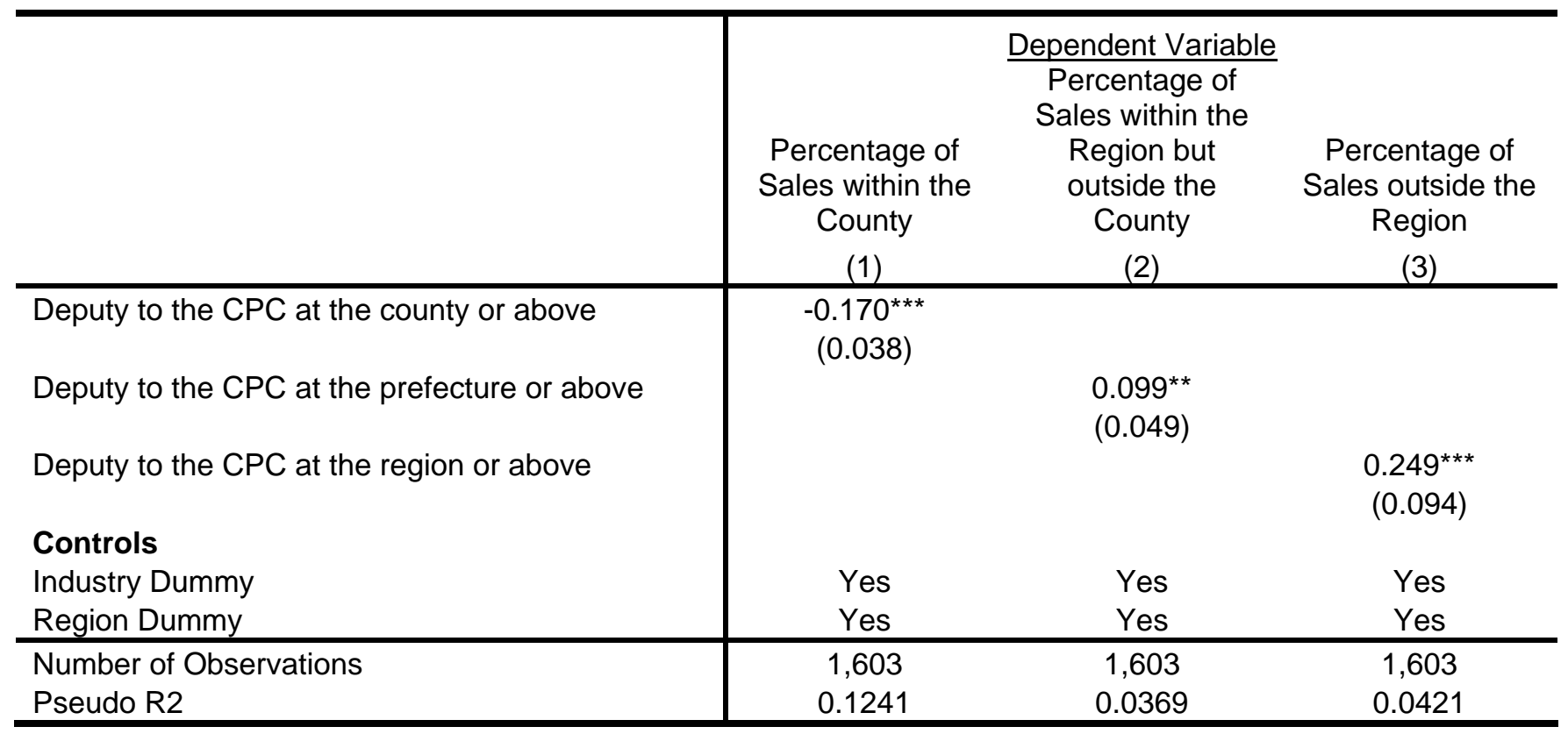

Standard errors, clustered at the region, are reported in the parenthesis. $*, * *, * * *$ respectively represent the significance at $10 \%, 5 \%$, and $1 \%$. 
Table 4: Political Connections and Trade Expansion, seemingly unrelated regression

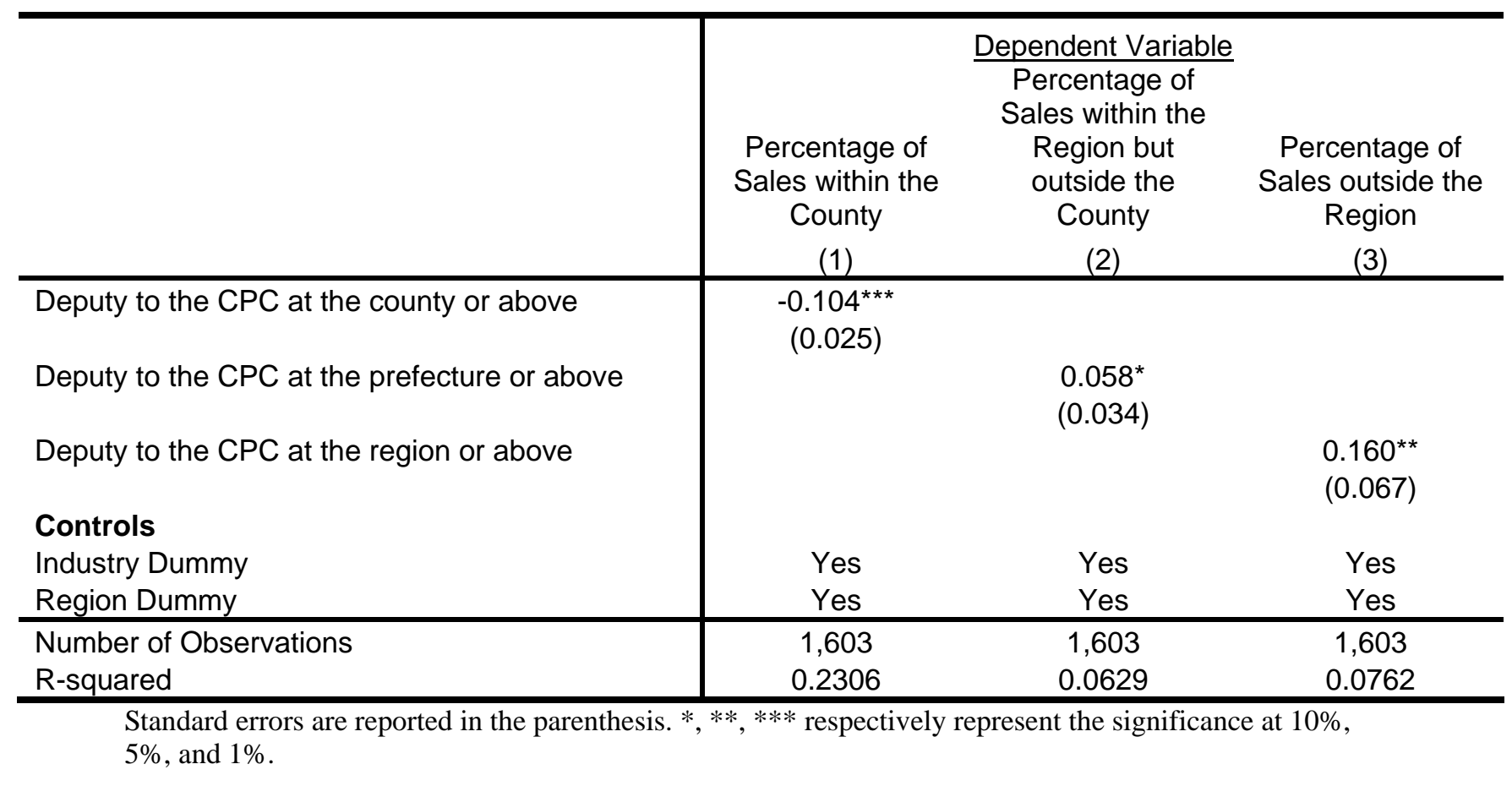


Table 5: Political Connections and Trade Expansion, with more controls

\begin{tabular}{|c|c|c|c|c|c|c|c|c|c|}
\hline & \multicolumn{3}{|c|}{$\begin{array}{l}\text { Percentage of Sales within the } \\
\text { County }\end{array}$} & \multicolumn{3}{|c|}{$\begin{array}{l}\text { Percentage of Sales within the } \\
\text { Region but outside the County }\end{array}$} & \multicolumn{3}{|c|}{$\begin{array}{c}\text { Percentage of Sales outside the } \\
\text { Region }\end{array}$} \\
\hline & $(1)$ & (2) & (3) & (4) & (5) & (6) & (7) & (8) & (9) \\
\hline Deputy to the CPC at the county or above & $\begin{array}{l}-0.159^{\star * *} \\
(0.040)\end{array}$ & $\begin{array}{l}-0.127^{\star \star \star} \\
(0.039)\end{array}$ & $\begin{array}{l}-0.135^{\star \star *} \\
(0.039)\end{array}$ & & & & & & \\
\hline Deputy to the CPC at the prefecture or above & & & & $\begin{array}{c}0.073 \\
(0.048)\end{array}$ & $\begin{array}{l}0.066 \\
(0.046)\end{array}$ & $\begin{array}{c}0.071 \\
(0.045)\end{array}$ & & & \\
\hline Age & $\begin{array}{c}-0.005^{\star \star \star} \\
(0.002)\end{array}$ & $\begin{array}{l}-0.004^{\star *} \\
(0.002)\end{array}$ & $\begin{array}{l}-0.004^{*} \\
(0.002)\end{array}$ & $\begin{array}{l}-0.001 \\
(0.002)\end{array}$ & $\begin{array}{l}-0.000 \\
(0.002)\end{array}$ & $\begin{array}{l}-0.000 \\
(0.002)\end{array}$ & $\begin{array}{c}0.004 \\
(0.002)\end{array}$ & $\begin{array}{l}0.004^{*} \\
(0.003)\end{array}$ & $\begin{array}{l}0.004^{*} \\
(0.003)\end{array}$ \\
\hline Education & $\begin{array}{l}-0.009 \\
(0.008)\end{array}$ & $\begin{array}{l}-0.003 \\
(0.007)\end{array}$ & $\begin{array}{l}-0.002 \\
(0.008)\end{array}$ & $\begin{array}{l}0.022^{\star \star \star} \\
(0.005)\end{array}$ & $\begin{array}{l}0.021^{\star \star \star} \\
(0.005)\end{array}$ & $\begin{array}{c}0.016^{\star \star \star} \\
(0.005)\end{array}$ & $\begin{array}{l}0.028^{* \star \star} \\
(0.011)\end{array}$ & $\begin{array}{l}0.027^{* *} \\
(0.012)\end{array}$ & $\begin{array}{l}0.019^{*} \\
(0.012)\end{array}$ \\
\hline Managerial Experience & $\begin{array}{l}0.002 \\
(0.031)\end{array}$ & $\begin{array}{l}-0.005 \\
(0.032)\end{array}$ & $\begin{array}{l}-0.012 \\
(0.033)\end{array}$ & $\begin{array}{c}0.022 \\
(0.024)\end{array}$ & $\begin{array}{l}0.017 \\
(0.024)\end{array}$ & $\begin{array}{c}0.014 \\
(0.025)\end{array}$ & $\begin{array}{c}0.020 \\
(0.047)\end{array}$ & $\begin{array}{l}0.013 \\
(0.047)\end{array}$ & $\begin{array}{c}0.009 \\
(0.047)\end{array}$ \\
\hline Party Member & $\begin{array}{l}0.004 \\
(0.031)\end{array}$ & $\begin{array}{l}-0.012 \\
(0.029)\end{array}$ & $\begin{array}{l}-0.016 \\
(0.028)\end{array}$ & $\begin{array}{l}0.017 \\
(0.038)\end{array}$ & $\begin{array}{c}0.020 \\
(0.038)\end{array}$ & $\begin{array}{c}0.032 \\
(0.039)\end{array}$ & $\begin{array}{l}-0.032 \\
(0.036)\end{array}$ & $\begin{array}{l}-0.032 \\
(0.039)\end{array}$ & $\begin{array}{l}-0.018 \\
(0.038)\end{array}$ \\
\hline Firm Characteristics & & & & & & & & & \\
\hline Firm Age & & $\begin{array}{l}-0.049^{\star} \\
(0.029)\end{array}$ & $\begin{array}{l}-0.057^{\star} \\
(0.029)\end{array}$ & & $\begin{array}{c}0.013 \\
(0.019)\end{array}$ & $\begin{array}{c}0.017 \\
(0.018)\end{array}$ & & $\begin{array}{l}-0.058 \\
(0.043)\end{array}$ & $\begin{array}{l}-0.053 \\
(0.040)\end{array}$ \\
\hline Firm Size & & $\begin{array}{c}-0.054^{\star \star *} \\
(0.013)\end{array}$ & $\begin{array}{c}-0.053^{\star \star *} \\
(0.012)\end{array}$ & & $\begin{array}{c}0.005 \\
(0.014)\end{array}$ & $\begin{array}{c}0.004 \\
(0.013)\end{array}$ & & $\begin{array}{c}0.013 \\
(0.015)\end{array}$ & $\begin{array}{c}0.014 \\
(0.015)\end{array}$ \\
\hline Other Controls & & & & & & & & & \\
\hline Industry Dummy & Yes & Yes & Yes & Yes & Yes & Yes & Yes & Yes & Yes \\
\hline Region Dummy & Yes & Yes & Yes & Yes & Yes & Yes & Yes & Yes & Yes \\
\hline Headquarters Location Dummy & No & No & Yes & No & No & Yes & No & No & Yes \\
\hline $\begin{array}{l}\text { Number of Observations } \\
\text { Pseudo R2 }\end{array}$ & $\begin{array}{l}1,589 \\
0.1279\end{array}$ & $\begin{array}{c}1,511 \\
0.1392\end{array}$ & $\begin{array}{c}1,511 \\
0.1451\end{array}$ & $\begin{array}{l}1,589 \\
0.0460\end{array}$ & $\begin{array}{c}1,511 \\
0.0459\end{array}$ & $\begin{array}{l}1,511 \\
0.0526\end{array}$ & $\begin{array}{c}1,589 \\
0.0498\end{array}$ & $\begin{array}{c}1,511 \\
0.0519\end{array}$ & $\begin{array}{c}1,511 \\
0.0614\end{array}$ \\
\hline
\end{tabular}

Standard errors, clustered at the region, are reported in the parenthesis. *, **, *** respectively represent the significance at $10 \%, 5 \%$, and $1 \%$. 
Table 6: Political Connections and Trade Expansion, instrumental variable estimation

\begin{tabular}{l|cc}
\hline & $\begin{array}{c}\text { Second Stage } \\
\text { Dependent Variable } \\
\text { Deputy to the } \\
\text { CPC at the } \\
\text { Percentage of } \\
\text { Sales within the } \\
\text { County } \\
(1)\end{array}$ & $\begin{array}{c}\text { First Stage } \\
\text { county or above } \\
(2)\end{array}$ \\
\hline Deputy to the CPC at the county or above & $-1.175^{\star *}$ & $(0.590)$ \\
First Job as Government Cadre or Soldier & & $0.069^{\star *}$ \\
Controls & & $(0.035)$ \\
Industry Dummy & Yes & Yes \\
Region Dummy & Yes & 1,419 \\
\hline Number of Observations & 1,419 & Yes \\
\hline
\end{tabular}

Standard errors, clustered at the region, are reported in the parenthesis. $*, * *, * * *$ respectively represent the significance at $10 \%, 5 \%$, and $1 \%$. 
Table 7: Political Connections and Trade Expansion, sub-sample

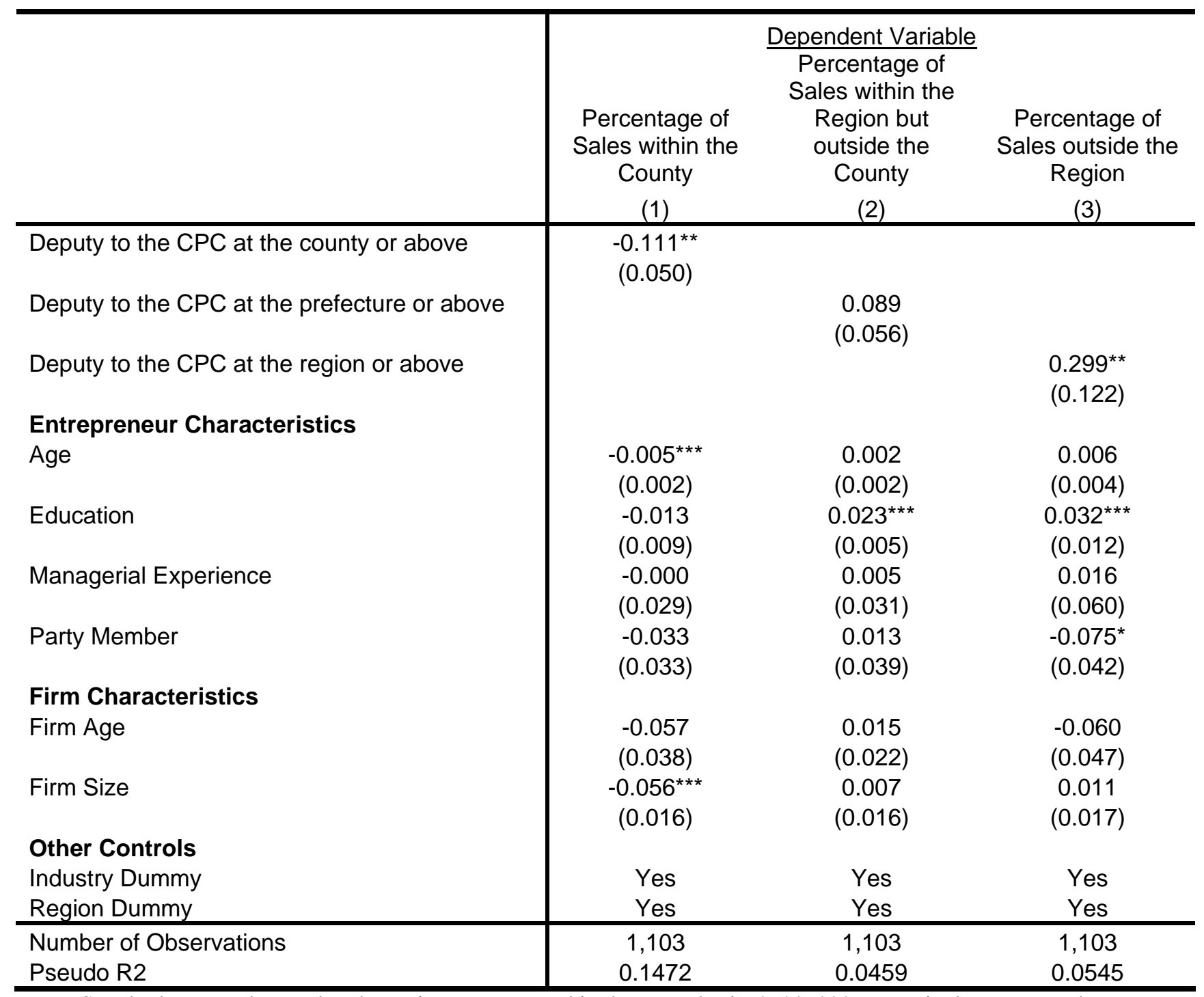

Standard errors, clustered at the region, are reported in the parenthesis. ${ }^{*}, * *, * * *$ respectively represent the significance at $10 \%, 5 \%$, and $1 \%$. 
Table 8: Political Connections and Trade Expansion, role of position in the CPC

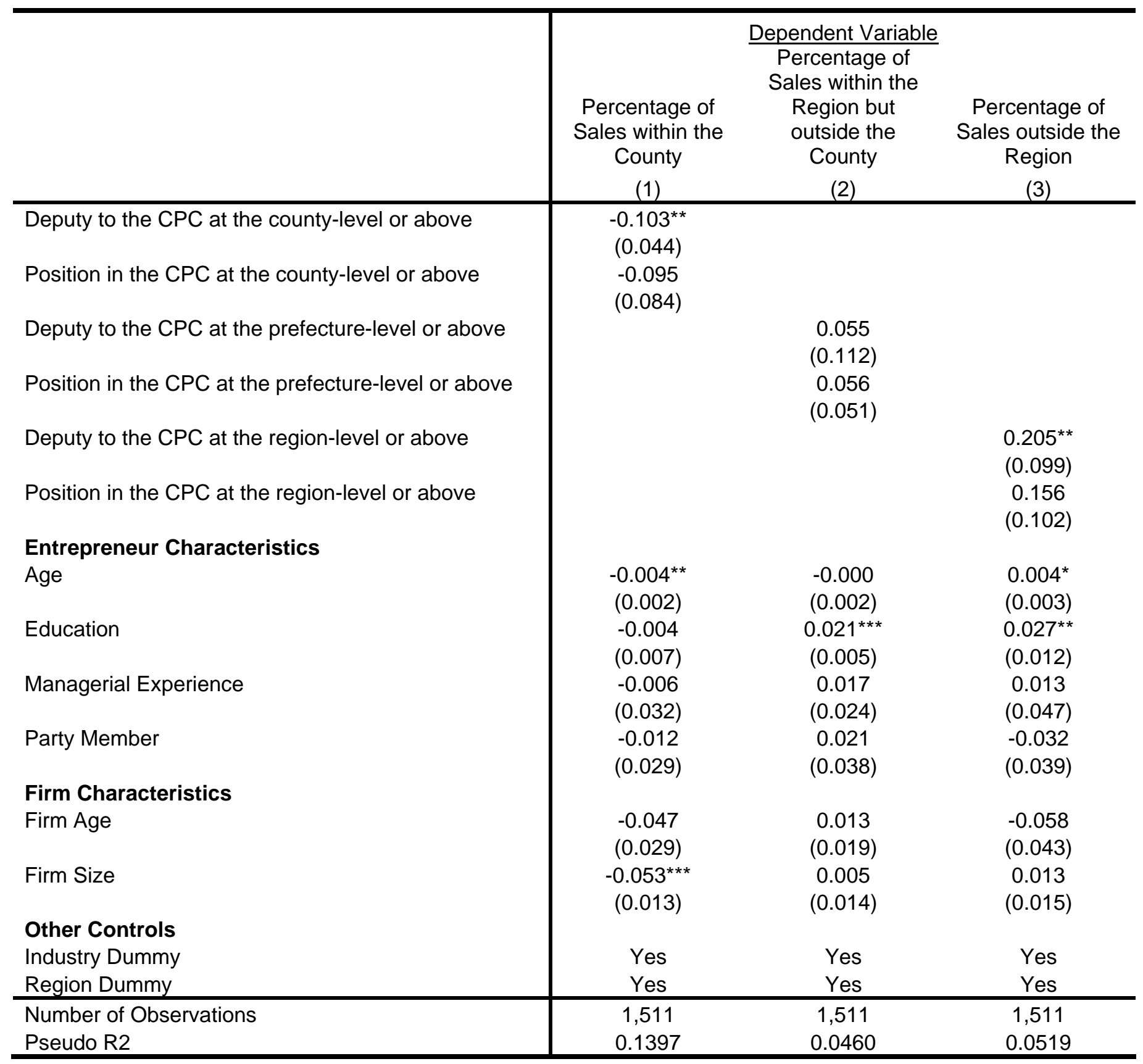

Standard errors, clustered at the region, are reported in the parenthesis. *, **, *** respectively represent the significance at $10 \%, 5 \%$, and $1 \%$. 
Table 9: Political Connections, Economic Institutions and Trade Expansion

\begin{tabular}{|c|c|c|c|}
\hline & \multicolumn{3}{|c|}{$\begin{array}{c}\text { Dependent Variable: Percentage of Sales outside the } \\
\text { Region }\end{array}$} \\
\hline & $(1)$ & $(2)$ & $(3)$ \\
\hline Deputy to the CPC at the region or above & $\begin{array}{l}0.343^{* * *} \\
(0.090)\end{array}$ & $\begin{array}{c}3.416^{\star * *} \\
(0.730)\end{array}$ & $\begin{array}{l}0.214^{\star \star} \\
(0.100)\end{array}$ \\
\hline Deputy to the CPC at the region or above * Property Rights Institutions & $\begin{array}{l}-37.525^{\star \star \star} \\
(13.278)\end{array}$ & & \\
\hline Deputy to the CPC at the region or above * Contracting Institutions & & $\begin{array}{c}-0.722^{\star \star \star} \\
(0.179)\end{array}$ & \\
\hline Deputy to the CPC at the region or above * Financial Institutions & & & $\begin{array}{l}1.073 \\
(0.852)\end{array}$ \\
\hline Entrepreneur Characteristics & & & \\
\hline Age & $\begin{array}{l}0.004^{*} \\
(0.003)\end{array}$ & $\begin{array}{l}0.004^{*} \\
(0.003)\end{array}$ & $\begin{array}{l}0.004^{*} \\
(0.002)\end{array}$ \\
\hline Education & $\begin{array}{l}0.026^{\star *} \\
(0.012)\end{array}$ & $\begin{array}{l}0.026^{* *} \\
(0.012)\end{array}$ & $\begin{array}{l}0.024^{\star *} \\
(0.011)\end{array}$ \\
\hline Managerial Experience & $\begin{array}{l}0.016 \\
(0.047)\end{array}$ & $\begin{array}{c}0.014 \\
(0.047)\end{array}$ & $\begin{array}{l}0.019 \\
(0.046)\end{array}$ \\
\hline Party Member & $\begin{array}{l}-0.029 \\
(0.039)\end{array}$ & $\begin{array}{l}-0.032 \\
(0.039)\end{array}$ & $\begin{array}{l}-0.029 \\
(0.037)\end{array}$ \\
\hline Firm Characteristics & & & \\
\hline Firm Age & $\begin{array}{l}-0.057 \\
(0.043)\end{array}$ & $\begin{array}{l}-0.057 \\
(0.043)\end{array}$ & $\begin{array}{l}-0.056 \\
(0.041)\end{array}$ \\
\hline Firm Size & $\begin{array}{c}0.013 \\
(0.015)\end{array}$ & $\begin{array}{c}0.013 \\
(0.015)\end{array}$ & $\begin{array}{c}0.011 \\
(0.014)\end{array}$ \\
\hline Other Controls & & & \\
\hline Industry Dummy & Yes & Yes & Yes \\
\hline Region Dummy & Yes & Yes & Yes \\
\hline $\begin{array}{l}\text { Number of Observations } \\
\text { Pseudo R2 }\end{array}$ & $\begin{array}{c}1,511 \\
0.0536\end{array}$ & $\begin{array}{c}1,511 \\
0.0530\end{array}$ & $\begin{array}{c}1,511 \\
0.0562\end{array}$ \\
\hline
\end{tabular}

Standard errors, clustered at the region, are reported in the parenthesis. ${ }^{*}, * *, * * *$ respectively represent the significance at $10 \%, 5 \%$, and $1 \%$. 